\title{
Constructing Trustworthy Historical Narratives: Criteria, Principles, and Techniques
}

\author{
Michael J. Gill \\ University of Oxford \\ Saïd Business School \\ Park End Street, Oxford, OX1 1HP, United Kingdom. \\ Email: MichaelGill5@gmail.com \\ David James Gill \\ University of Nottingham \\ School of Politics and International Relations \\ University Park, Nottingham, NG7 2RD, United Kingdom \\ Phone: Tel +44 (0) 1159514885 \\ Email: David.Gill@nottingham.ac.uk
}

\author{
Thomas J. Roulet \\ King's College London, \\ Franklin Wilkins Building, \\ 150 Stamford Street, London, SE19NH, United Kingdom. \\ Phone: +44 (0)20 78365454 \\ Email: thomas.roulet@kcl.ac.uk
}

\section{$\underline{\text { Acknowledgements }}$}

The authors would like to thank each of the three reviewers for their constructive and supportive comments in developing this article. 


\title{
Constructing Trustworthy Historical Narratives: Criteria, Principles, and Techniques
}

\begin{abstract}
Organizational scholars increasingly recognize the value of employing historical research. Yet the fields of history and organization studies struggle to reconcile. In this article, we contend that a closer connection between these two fields is possible if organizational historians bring their role in the construction of historical narratives to the fore and open their research decisions up for discussion. We provide guidelines to support this endeavor, drawing on four criteria that are prevalent within interpretive organization studies for developing the trustworthiness of research: credibility, confirmability, dependability and transferability. In contrast to the traditional use of trustworthiness criteria to evaluate the quality of research, we advance the criteria to encourage historians to generate more transparent narratives. Such transparency allows others to comprehend and comment on the construction of narratives thereby building trust and understanding. We convert each criterion into a set of guiding principles to enhance the trustworthiness of historical research, pairing each principle with a practical technique gleaned from a range of disciplines within the social sciences to provide practical guidance.
\end{abstract}

\section{Keywords}

Narrative History, Naturalistic inquiry, Qualitative Research, Trustworthiness. 


\section{Introduction}

Organizational scholars increasingly recognize the value of incorporating historical evidence into their theories. Researchers suggest historical accounts provide new perspectives that could infuse organizational theories with a greater sensitivity to the issues raised by the humanities (Zald, 1993;Burrell, 1997), a richer understanding of organizations (Sydow, Schreyögg and Koch, 2009) and a new outlook on accepted assumptions (Jacques, 2006). Yet organization studies continues to neglect history (Alvesson and Sköldberg, 2009; Warren and Tweedale, 2002) and retains an ahistorical character (Üsdiken and Kieser, 2004) as the two fields of research struggle to reconcile (Greenwood and Bernardi, 2014).

In this article, we contend that organizational historians could foster a closer connection between these two fields by making the conduct of their research and the construction of their narratives more transparent. By accounting for and justifying their methodological decisions, organizational historians would provide organizational scholars with an opportunity to build greater trust in their work and facilitate more open conversations. Currently, however, whilst there is some emerging practical guidance for organizational historians (see Kipping, Wadhwani and Bucheli, 2014), this remains limited. As Zald (1996, p. 256) pointed out, "there is little explicit attention to issues of historiography and historical method in contemporary organisational studies."

In particular, there is a paucity of guidance for narrative historians who define history as a narrative construction or a form of literature, where historical reality is discursively produced (Munslow, 2006). From this perspective, the past is not discovered but is, instead, a text that has been created by historical researchers, each of whom "produce $a$ historical account instead of the historical account" (Coraiola, Foster and Suddaby, 2015, p. 211). As both historians (White, 1973;Mink, 1970) and organizational scholars (Rhodes and Brown, 2005;Hatch, 1996;Rhodes, 2001) who adopt a narrative perspective have recognized, the 
writing of such narratives is a process of interpretation. Historical texts can be better understood as "stories" rather than privileged truth claims" (Chia, 1996, p. 68). As such, guidance should support narrative historians in disclosing and explaining how they have produced their rendition of the past without assuming that objectivity is possible.

The objective of this article is to develop criteria and associated techniques to support organizational historians in bringing their role in the construction of historical narratives to the fore and opening their research decisions up for discussion. To do so, we draw on the established criteria of trustworthiness in qualitative research: credibility, confirmability, dependability and transferability (Lincoln and Guba, 1985; Shah and Corley, 2006;Lincoln and Guba, 2013;Guba, 1981). A variety of organizational scholars continue to employ these criteria in their qualitative research as they offer techniques to enhance the quality of their interpretations (e.g., Gioia, Price, Hamilton and Thomas, 2010;Corley, 2004;Balogun and Johnson, 2004; Trethewey, 1999;Bradshaw-Camball and Murray, 1991). We purposefully employ the notion of trustworthiness to emphasize that judgments of truth or plausibility operate within particular ideological, spatial or temporal bounds. As Hayden White pointed out "what was good history at one time is judged by an equally professional competent group in a later generation as being bad history" (O'Connor, Hatch, White and Zald, 1995: 131).

We therefore advance an understating of trustworthiness not as a set of evaluative criteria for assessing or judging which historical narrative is closest to the truth nor to stipulate what constitutes good historical research (Czarniawska, 1997). Instead, we develop the criteria to provide a framework to guide researchers in generating more transparent historical narratives that allow other scholars to build trust in them. Trust describes the willingness to make oneself vulnerable to another person or a decision to take risk and to depend on the trustee, to some extent (Fulmer and Gelfand, 2012). We contend that greater understanding is likely to lead to greater trust. As scholars have tended to apply the 
traditional criteria of trustworthiness in terms of contemporary field-based research, they have developed techniques that are largely atemporal and unamenable to historical scholarship. As such, we propose new techniques to render the criteria of trustworthiness more relevant to constructing transparent historical narratives, illustrating each with exemplars from across the social sciences.

These criteria and techniques contribute to the recent emergence of historical methods for organization scholars (e.g., Yates, 2014a;Lipartito, 2014;Kipping et al., 2014). They are valuable as they would encourage narrative historians' responsibility for what they write, bringing to the fore their textual choices in selecting and emplotting narratives (Rhodes \& Brown, 2005). Such reflexive responsibility prevents the researcher presuming or claiming authority (Hatch, 1996) and recognizes that a narrative can be open to reframing. This encourages other scholars to confront and understand the decisions underpinning an historical narrative and, potentially, to question these and consider alternative explanations. Advocates of such reflexivity point to its potential to create dialogue with others (Gabriel, 2015), where "more open conversations will generate more perspectives, ideas, and insight that inform emerging theoretical insights" (Hibbert, Sillince, Diefenbach and Cunliffe, 2014, p. 292). Thus these criteria support the development of new contributions within the interpretive traditions (Prasad and Prasad, 2002;Zald, 1996).

Three sections structure this article. First, we briefly introduce the philosophical notion of history as an interpretive process of constructing a narrative as opposed to a scientific endeavor. Narrative history views history as an imaginative interpretation of evidence from the past. Second, we introduce the interpretivist approach of naturalistic inquiry that offers criteria for enhancing trustworthiness. We highlight that existing techniques of trustworthiness are largely atemporal and evaluative. We therefore develop new, historically sensitive techniques that encourage transparency for each of the four criteria 
of trustworthiness. Third, we consider the potential implications of employing these criteria and techniques in the development and publication of historical narratives in organizational research.

\section{Competing conceptualizations of history: From science to stories}

Organizational theorists often treat the work of historians as a repository of facts from which they can select evidence to support their theories (Clark and Rowlinson, 2004;Kieser, 1994). We contend, however, that that in drawing on the work of historians, theorists are drawing on interpretations and not neutral evidence. This position can be supported by tracing briefly the evolving conception of historical knowledge within the philosophy of history. In particular, by contrasting the traditional notion of history as a scientific endeavor with the emergence of an interpretivist and narrative perspective.

A variety of scholars have traced the contemporary discipline of history back to the work of Leopold Von Ranke, an early nineteenth century German historian (Lustick, 1996;Megill, 1991;Iggers, 1984). Ranke sought to establish the work of historians as a scientific activity, propagating specific procedures for the analysis of archives and documents that could reveal the past 'as it actually was' (Von Ranke, 2010;Gil, 2009). These new methodological rules to understand history reflected his claim of history as an objective science (Rüsen, 1990) and this notion continued to garner popularity amongst historians (e.g., Bury, 1968;Elton, 2002). This conceptualization also found philosophical support in the midtwentieth century from Carl Gustav Hempel. Hempel sought to establish general laws, which "have quite analogous functions in history and in the natural sciences, that they form an indispensible instrument of historical research" (Hempel, 1942, p. 35). Hempel argued that scientific explanations worked by subsuming events under general laws and that, for history to be scientific, historical explanation must do the same. 
During the twentieth century, however, scholars like Novick (1988) began to challenge the notion of history as a science or the existence of "objectivity" more broadly. Philosophers articulated a more subjective view of history as constructed by the historian (e.g., Croce, 1921;Collingwood, 2005;Dray, 1971). Building on the earlier conceptualizations of history as an interpretation and construction of the past, historians such as Hayden White and others began to conceive history as a form of linguistic practice and writing (White, 1975;Carr, 1986;Mink, 1970;Ricoeur, 1965;Roth, 1988;Stone, 1979). Whilst many subtle differences persist amongst self-identified narrative historians, such scholars drew parallels between literary theory and historical accounts. Narrative history is a particular mode of historical writing that seeks to organize evidence imaginatively into a coherent story of the past. Prominent philosophers of narrative history like Hayden White argue that any 'past', which is by definition comprised of events and structures that are no longer perceivable, can only be represented in either consciousness or discourse in an imaginary way (White, 1984, p. 2). Nonetheless, an historical narrative differs from fiction because it is obligated to rest on evidence, including the critical assessment of other historians' interpretations (Mink, 1970). Narrative approaches to the study of history continue to be popular today and represent an increasingly prominent way of understanding the role of historians as interpreters of the past (Roberts, 2001;Munslow, 2006).

Yet narrative history poses a challenge for those who wish to use it to make claims about the past. As Louis Mink (2001, p. 219) articulated, there is a "dilemma about the historical narrative: as historical it claims to represent, through its form, part of the real complexity of the past, but as narrative it is a product of imaginative construction, which cannot defend its claim to truth by any accepted procedure of argument or authentication." Scholars of organizational narratives have pointed out similar issues: "Writing research is a creative act that problematizes standard distinctions between fact and fiction" (Rhodes and 
Brown, 2005, p. 483). Further complicating this issue, the creative, imaginative or subjective decisions that underpin the construction of historical narratives typically remain obscured and opaque. This stems, at least in part, from a lack of guidance for organizational scholars who wish to construct historical narratives (Clark and Rowlinson, 2004;Goldthorpe, 1991;Barrett and Srivastval, 1991). How, then, can proponents of narrative history provide greater insight into and transparency of their research to allow other scholars to understand their choices and decisions? In particular, how do organizational historians do so in a way that encourages organizational theorists to engage with their work? Viable answers to these questions exist in the precedents set by scholars of naturalistic inquiry and the concept of trustworthiness.

\section{Toward trustworthy historical research}

Naturalistic inquiry emerged as an alternative to positivist research approaches and was largely developed through the combined efforts of Norman Denzin, Egon Guba and Yvonna Lincoln (Lincoln and Guba, 1985, 2013;Guba, 1981;Denzin, 1971;Lincoln, 1995;Denzin, 1989). The term naturalistic refers to investigators studying every-day or natural situations instead of intentionally manipulating variables in a research setting. For many organizational theorists, naturalistic inquiry is a useful research approach in which insights are induced through the interpretation of evidence (e.g., Greenwood and Suddaby, 2006;Garud, Jain and Kumaraswamy, 2002). Indeed, organizational scholars continue to employ the criteria and associated techniques of trustworthiness to their research across a range of journals and research topics (e.g., Gioia et al., 2010;Corley, 2004;Balogun and Johnson, 2004;Trethewey, 1999;Bradshaw-Camball and Murray, 1991).

Trustworthiness equates to an inquirer making their research practices visible, and therefore auditable, enabling others to gain a richer insight into how their findings were produced. 'Trustworthiness', instead of 'truth', reflects the idea that validation is displaced 
"from its traditional location in a presumably objective, nonreactive, and neutral reality, and moves it to the social world - a world constructed in and through our discourse and actions, through praxis" (Mishler, 1990, p. 420). This notion of trustworthiness is particularly relevant to narrative history as it stresses the importance of understanding not just 'what' is produced but also how it is produced, as assessments of what is plausible will change over time.

Lincoln and Guba (1985) suggest four criterions for establishing trustworthiness within the naturalistic paradigm: credibility, confirmability, dependability and transferability. Whilst a variety of other guidelines exist for qualitative research (see Seale, 1999), Lincoln and Guba's criteria remain pervasive and popular in organization studies. Given qualitative organizational scholars continued use of their criteria, the notion of trustworthiness and associated criteria appears to be a useful source to develop a framework to enhance the transparency of historical organization studies. Indeed, the "similarities between historical research and qualitative longitudinal research on organizations provide a useful starting place in legitimizing historical work on organizations" (Yates, 2014a, p. 282).

In their current form, however, naturalistic inquiry's techniques of trustworthiness have had limited engagement with notions of history or time. This does not mean that naturalistic inquiry, itself, is resistant to the study of events over time or to historical inquiry. For instance, it seeks to challenge the "ahistoric bias of many sociological schemes" and posits that "naturalists inevitably become micro-historians" due to their concern for how previous acts inform subsequent conduct (Denzin, 1971, p. 173; 1989). Nonetheless, temporality is largely absent from the texts of naturalistic inquiry, even in the discussion of its core assumptions (e.g., Guba and Lincoln, 1982;Denzin, 1971) and its techniques do not currently lend themselves to historical scholarship.

The absence of temporal considerations is problematic if naturalistic inquiry's notion of trustworthiness is to be applied directly to historical narratives. As Tilly (1999) points out, 
the application of an approach to historical cases can remain ahistorical or even anti-historical if it disregards the time-space contexts of the social processes under investigation. Although time is not the same as history (Rowlinson, Hassard and Decker, 2013;Suddaby, Foster and Mills, 2014), temporality is a defining characteristic of processes that can be meaningfully distinguished as history (Büthe, 2002). It is time that demarcates historical from nonhistorical research (Griffin, 1992). Thus, new techniques for building trustworthiness are required if organizational scholars are to progress from their largely cross-sectional approaches to the study of historical events (Haveman, 1993).

Thus, the following subsections translate each of Lincoln and Guba's $(1985,2013)$ four criterions of trustworthiness into new techniques that appreciate time, are more applicable to historical sources. Table 1 outlines the conversion of Lincoln and Guba's (1985;Guba, 1981) criteria. The proposed principles and techniques are different but complementary, reinforcing one another. The table also includes examples from across the social sciences where scholars have practiced the principle or some aspect of each technique.

Please insert Table 1 about here

\section{Credibility}

Lincoln and Guba (1985, p. 213) posit "a major trustworthiness criterion is credibility in the eyes of the information sources, for without such credibility the findings and conclusions as a whole cannot be found credible by the consumer of the inquiry report." The authors suggest that this criterion is satisfied when their sources agree with or have confidence in the researchers' interpretations or reconstructions. This is similar to what the narrative scholar 
Catherine Riessman (1993) describes as correspondence, which refers to refers to the process of taking the analysis back to those studied for verification and/or further dialogs.

Given the absence of many historical sources that can 'agree' with the researcher, we suggest that it is the responsibility of historical researchers to clarify, as far as possible, why readers should believe in their narratives. Indeed, Lincoln and Guba go on to conclude that ultimately the consumers of the study decide whether it is credible. As such, we contend that organizational historians can build credibility by detailing how they engaged critically with the differing perspectives that shaped the construction of their historical narratives.

It is important to stress here that many narrative researchers are skilled storytellers, who can convince reviewers and researchers of the likelihood of their interpretations. As with most interpretive research, a researcher can choose and emphasize particular perspectives to narrate their interpretation of history. As such, this criterion of credibility for historical research is not proposed as a way to assess the truthfulness of an historical narrative. Rather, it serves to encourage both the researcher to be critical of sources and to consider contrasting perspectives, clarifying how a narrative account advances or challenges the existing historiography. This would benefit both researcher and reviewer as it would render the narrative's distinctiveness - and therefore contribution - more apparent and facilitate discussion. This section proffers two principles of credibility: engage with the content and context of sources and discuss interpretations.

Engage with the content and context of sources. This principle reflects Lincoln and Guba's (1985) original credibility techniques of prolonged engagement and persistent observation, where a researcher engages with their study's participants or site of study for extended periods. These techniques seek to uncover and address the distortions introduced by respondents and the influence of respondent's context. The underlying principle of sustained interaction remains valuable for historical analysis, which should seek to build a 
comprehensive picture of an historical event. As Ingram (1997) notes, many social scientists pay scant attention to the past, utilizing fragments of history without reading enough. This is particularly true in organizational theory, where scholars cite historical sources sparingly often just to provide a background (Rowlinson, Hassard, \& Decker, 2013). Prolonged engagement with the relevant historiography and sources provides researchers with the opportunity to identify debates, discontinuities or distortions that may not be apparent initially. By reading more about particular historical events and engaging with the explicit meanings and implicit assumptions of a range of sources, organizational historians can achieve the same benefit as researchers who engage with their site of study for prolonged periods: a more nuanced and richer interpretation of historical evidence.

A technique that supports researchers in meeting the principle of engaging with the content and context of sources is source criticism. Source criticism refers to "a "hermeneutics of suspicion', an epistemic stance which mandates that the available testimony be probed comprehensively, not for explicit meanings and messages only, but for implicit assumptions and articulate silences as well" (Bryant, 2000, p. 508). This emphasis on history as a hermeneutical and interpretive process harks back to philosophers like Heidegger who insisted that individuals interpret from their historicality (Heidegger, 1996) and therefore that historical sources are replete with biases. As Carr (1961, p. 16-17) famously stated, "when we take up a work of history, our first concerns should not be with the facts it contains but with the historian who wrote it." It is no surprise, then, that social scientists have expounded source criticism as a vital procedure in producing credible interpretations of historical sources (Bryant, 2000;Bucheli and Wadhwani, 2014) and called for close attention to the context of sources (Robinson and Kerr, 2015).

There are a growing number of examples in organizational history where scholars have interrogated historical sources to establish who produced them and why. Bucheli and 
Wadhwani (2014) cite Arndt and Bigelow's (2005) study of the masculinizing of hospital administration over the course of the twentieth century as a good example of source criticism. Arndt and Bigelow (2005) looked beyond the content of the American Hospital Association's hospital trade journals and detailed in their appendices the various committees that each of the editors sat on. They considered who authored the journals and their purpose for writing. In doing so, they showed how occupations masculinize not only through societal factors, as had been assumed, but also from within, as the journal reflected the more masculine and scientific approach of its editors.

Discuss interpretations. This principle is analogous to Lincoln and Guba's (1985) suggestion that an inquirer employ peer debriefing. Peer debriefing describes an inquirer exposing their work to a disinterested peer to keep the inquirer 'honest', to test emerging hypotheses and identify assumptions or feelings that may cloud good judgment. The underlying principle of peer debriefing is to engage with individuals who can share insights into the phenomena under study and react to emergent theories or findings.

As such, we suggest the technique of expert (historian) checks. This technique refers to organizational historians engaging with historians that possess relevant expertise to discuss their interpretations of the past. Theorists of international relations, for instance, have certainly benefited from discussion with diplomatic historians, where such 'cross fertilization' and 'collaboration' produces more contextualized theories (George, 1997). In one famous example, the political scientist Richard Smoke (1977) elaborated a theory concerning the escalation of war across five different historical case studies (see George and Bennett, 2005). In developing this study, Smoke asked historians to recommend suitable studies for each case and to review his case studies prior to publication. As a result, scholars continue to describe Smoke's work as one of the most thorough and valuable studies on the subject (Byman and Waxman, 2002, p. 40). In this way, although there appear to be limited 
examples of organizational historians applying this technique, there is a precedent of successful collaboration within the social sciences. Fostering collaborative relationships between theorists and historians is likely to prove mutually rewarding and to bring the inherent issues of interpretation to the fore.

\section{Confirmability}

Confirmability refers to researchers' attempts to identify some of their assumptions and predilections in the findings of their study through explicit consideration of their interpretation of the data. This criterion entails a researcher seeking to recognize the assumptions or values that shape their research. Whilst assumptions are inescapable, they are "not unknowable" if reflexivity is practiced and the relationship between the narrator and the story is explored (Hatch, 1996, p. 360). Given that the generation and interpretation of data depend on the actors involved (Hibbert et al., 2014), narrative scholars could consider how they can attempt to explore their assumptions in the production of an historical representation. In support, we propose two principles of confirmability of historical narratives: reveal underlying epistemological assumptions and ensure interpretations are grounded in evidence.

Reveal underlying assumptions. This principle reflects Guba's (1981; with reference to Ruby, 1980) insistence that researchers should intentionally reveal to their audience the underlying epistemological assumptions, which cause them to formulate a set of questions in a particular way and to present their findings in a particular way. Guba described keeping a reflexive journal as an 'indispensable' technique. A reflexive journal is a "diary in which the investigator on a daily basis, or as needed, records a variety of information about self (hence the term "reflexive) and method" (Lincoln and Guba, 1985, p. 327). 
However, given the rarity of organization studies that incorporate a reflexive log, we suggest meeting the principle of revealing assumptions by a researcher explicitly stating their ontological, epistemological and historiographical assumptions. There are a variety of helpful resources in this regard. For instance, Coraiola et al. (2015) point out that all historical scholars adopt an ontological view on the nature of history, whether they were aware of their position or not. These authors outline three different ontological perspectives of history (reconstructionism, constructionism and deconstructionism), on which researchers could reflect.

Another way to bring the assumptions of the historical researcher to light is through a researcher identifying their school or strategy of historiography. This technique refers to researchers stating their epistemological assumptions at the outset of their study. As Lustick (1996, p. 615) describes, instead of treating all historiography as one unsynthesized but synthesizable historical record, one option available to researchers is to "identify the particular approach or school of historiography whose work is most convincing, and indicate its distinctive (even if implicit) theoretic commitments and biases." A helpful resource for organizational historians in this regard is the work of Rowlinson et al. (2013), who outline alternative strategies or different ways of knowing the past for researching and writing history. For example, they contrast one strategy of 'corporate history' that consists of a holistic and objectivist narrative of named corporate entity with 'ethnographic history' derived from reading sources 'against the grain' to recover practices and meanings from organizations. McKinlay's (2002, p. 596) investigation of Scottish banking provides an exemplar within organization studies, by clearly stating that his research employs a Foucauldian analysis in contrast to 'conventional' accounts. By explicating such assumptions, researchers are indicating that their claims are confirmable only within the boundaries of particular beliefs about the nature of historical knowledge. 
Ensure interpretations are grounded in evidence. This principle underlies Guba's (1981) original technique of a confrmability audit. In terms of such an audit, Lincoln and Guba (1985) draw on the work of Halpern (1983;see also Schwandt and Halpern, 1988), who emphasized that researchers should be able to provide a trail of the materials they use to construct their findings. This is analogous to fiscal accounts, where an auditor can assess a final financial report. However, the use of auditing is infrequent in organization studies, not least because it is very demanding on auditors who must deal with large amount of qualitative data (see Belk, Sherry and Wallendorf, 1988). Furthermore, scholars have noted that the analogy of fiscal reporting is providing a false ideal that an interpretive research process can ever be fully transparent or explicit (Hammersley, 1997).

As such, we proffer the technique of active citation and footnoting to enable a researcher to provide a trail of evidence that corroborates some of their interpretations without suggesting that their work is fully auditable. Active citation is a relatively recent procedure advanced by Andrew Moravcsik in the field of international relations, which seeks to provide readers with clarity and confidence that evidence supports the interpretations presented. Moravcsik (2010, p. 31) describes how active citation rules oblige scholars to provide "concrete evidence for controversial empirical claims, annotated to explain precisely how the source supports the textual claim. The need to footnote precisely and annotate implies the use of a classic, not 'scientific,' form of footnotes, preferably on the page." Thus, as Tønnesson (2012) notes, the intention of active citation is to overcome the frequent practice of scholars employing imprecise and vague citations that lack page numbers or reference to specific points. In a further effort to provide transparent interpretations, Moravcsik (2010) suggests that these citations should contain a hypertext link to a reproduction or transcript of some part of the source that relates a controversial statement. The aim is to provide a sufficient amount of text to illuminate the process of interpretation, 
not necessarily to reproduce an entire source. Such transparency helps to provide confirmable interpretations of historical events and opens up more opportunities for criticism or counterinterpretations. Whilst these techniques are not commonplace in management journals, there are examples of organizational scholars being very thorough and precise in their use of references. For instance, Hassard (2012) provides a very rich and contextualized account of the Hawthorne Studies with a range of citations, including specific page references, alongside several pages of supporting notes and links to associated archives. In doing so, Hassard enabled readers to consider and confirm his interpretations.

\section{Dependability}

Lincoln and Guba (1985) posit that naturalistic inquirers are not objective observers but intimately involved in shaping their studies. This calls for interpretivist researchers to explain their approach and process of developing interpretations is dependable as they are only likely to yield credible results if they exhibit consistency. Narrative historians could consider how they conduct their research, explaining why they, for example, emphasize certain sources and not others. This criterion does not deny the existence of multiple interpretations of the past (Boje, 1995) but seeks to illuminate the process by which historians conducted research to construct their particular rendition of the past. The following paragraphs explicate how narrative historians may achieve dependability through two principles: adopt different approaches to research and allow others to comment on the process of research.

Adopt different approaches to research. This principle parallels Lincoln and Guba's (1985) technique of triangulation. This principle encourages researchers to utilize not only different sources but also different methods and researchers to gather and interpret data (for more detail on types of triangulation see Denzin, 1970). When possible, eliciting data from multiple sources allows researchers to determine if they provide different information. 
Different data collection methods may include interviews, observations or questionnaires. Multiple inquirers provide different experiences and perspectives when interpreting the data. The value in these forms of triangulation lies in their potential to establish and contrast competing interpretations that emerge from research, rendering the process of research more transparent and therefore more dependable.

As the political scientist Lustick (1996, p. 616) describes, one way to perform triangulation in terms of historical sources is to construct a narrative from the claims made by different historians despite their use of different archival sources or implicitly theoretic or political angles. Thies (2002, p. 357) explains that by "triangulating with different sources of evidence to maximize your archival coverage you should be able to reveal inaccuracies or biases in the individual sources". Similarly, researchers could examine different versions of the same document, such as government documents before and after declassification to refine their interpretations (Trachtenberg, 2009). In one example, O'Connor (1999) considered the early development of the Human Relations School at the Harvard Business School under the leadership of various individuals like Elton Mayo by triangulating both primary and secondary sources. Her investigation included primary sources from the library archives in Harvard Business School alongside the secondary sources of Elton Mayo's publications. This blend of sources helped to demonstrate how Harvard Business School constructed itself in relation to the economic, political and social debates of the time.

Similarly, historical studies that draw on the triangulation of methods or employ multiple modes of data collection strengthen the dependability of their interpretations. In the field of historical sociology, Skocpol (1984, p. 360) suggests that researchers could benefit from combining different methods, such as conducting archival investigations alongside investigating historians' work as secondary sources. Indeed, several scholars stress that theorists often employ historians' accounts uncritically, without reference to the archives 
(Lustick, 1996;Larson, 2001). Furthermore, though not always within the grasp of historical research, interviews with relevant individuals or statistical analyses of quantitative data could complement investigation into documents. For instance, Pettigrew's (2011) exploration of Imperial Chemical Industries' evolving culture, processes and strategy over twenty years has been praised for combining historical sources and interviews to provide a rich account (Clark and Rowlinson, 2004), although this reflects its consideration of the recent past.

Allow others to comment on the process of research. This principle corresponds with Guba's (1981) recommendation that naturalistic inquirers enable an external auditor to examine the processes whereby data were collected and analyzed, that underpin interpretations. This is to avoid 'creative accounting' and to ensure that the process of inquiry should fall within acceptable professional limits (Lincoln and Guba, 1985). Traditionally, this takes the form of an account of the process, typically in an investigator's daily journal.

To meet this underlying principle of dependability, without being reliant upon an auditor, we suggest that researchers explicate particular decisions, such as why they chose a specific source or how they reached a potentially contentious interpretation. This should reveal the analytical mechanisms through which the researcher went from data collection to the construction of the narrative. This is what Lustick (1996) refers to as 'explicit triage', which could be supplemented by notes that inform readers of alternative explanations and briefly account for the rejection of these explanations.

Political scientists have approached the 'audit' of competing historical explanations, through process tracing (Bennett, 2008;George and Bennett, 2005;Collier, 2011). Process tracing requires finding diagnostic evidence that provides the basis for descriptive inference within pragmatic limits. The goal is to use such evidence, which will have varying levels of probative value, to determine whether a sequence of events better fits those predicted by alternative explanations. As Bennett (2008, p. 705) explains, "This is closely analogous to a 
detective attempting to solve a crime by looking at clues and suspects and attempting to piece together a convincing explanation based on the detailed evidence that bears on means, motives, and opportunity." Whilst organizational scholars have begun to employ process tracing (e.g., Tippmann, Mangematin and Scott, 2013), it remains underutilised in historical organization studies. Nonetheless, there are examples in other social sciences, such as Elman's (2004) explicit use of process tracing to argue convincingly that France offered Louisiana for sale to the United States because European power considerations dominated its calculations. Process tracing also provides an opportunity to establish a dependable explanation of interpretations within organization studies.

\section{Transferability}

Naturalistic inquirers assume that generalizations of the rationalistic variety are not possible because phenomena are intimately tied to the particular contexts and times in which they are studied (Guba, 1981). This is particularly important for historical research given the risk of producing anachronistic explanations or findings. Nonetheless, researchers may be able to transfer their explanations or findings from one context to another context if there is a strong degree of fit. As such, scholars seeking to meet the criterion of transferability must be able to provide sufficient detail to contextualize their interpretations of an historical event, or what Guba and Lincoln (1994) refer to as a database, to facilitate future judgments about the transferability of findings to other contexts. As Riessman (1993, p. 21) states of narrative research "[t]he text is not autonomous of its context." This subsection therefore proposes two principles to contextualize and establish the transferability of historical interpretations: understand a particular case or set of cases in detail and permit comparison of context under study to other contexts. 
Build a richly contextualized account of the case(s) under study. This principle corresponds to Guba's (1981) suggestion that scholars should seek to maximize the range of information that informs emergent insights via the technique of theoretical sampling. This technique stands in contrast to statistical sampling and refers to a researcher determining their sample initially by pre-selection to explore a particular topic in a specific setting. As the researcher establishes interpretations that may generate theories within a particular context, they then develop their sample based on maximizing the range of information that relates to these emerging theories. In doing so, they build a more complete picture of the particular context under study whilst also refining the emerging theories. Numerous articles and texts equip organizational researchers with guidance on how to conduct theoretical sampling to develop theories (e.g., Strauss and Corbin, 1990;Eisenhardt, 1989).

We also suggest that scholars employ the technique of purposive and theoretical sampling, which requires little translation to historical sources. Given that history is a discipline of context (Goldthorpe, 1991), historical studies tend to focus on a particular phenomenon to provide rich detail. Yates (2014b) points out that most historians and historical treatments of organizations choose a historically significant phenomenon. Yet both rarely explore their sampling assumptions. A notable exception is Chandler's (1977) accounts of structural reorganization and the emergence of multidivisional forms of organization. According to Yates (2014b), Chandler's explicit focus on firms that adopted these reorganizations early could equate to a theoretical sample although he does not describe it as such but, nonetheless, offers a clear explanation of his sampling strategy. We contend that by building a rich contextualized narrative through appropriate sampling, scholars will be more easily able to identify fundamental differences between different historical cases and therefore more sensitive to the perils of anachronism when attempting to offer comparisons. 
Permit comparison of context under study to other contexts. This principle mirrors Guba (1981: 86) suggestion that researchers should collect rich data, arguing that it "is incumbent on investigators to provide the information necessary to test the degree of fittingness." That is to say, if a researcher collects ample data on the context of their study then this data may help future research to assess its similarities with different contexts. Whilst historians typically provide contextualized and rich descriptions (Megill, 1989), organizational scholars' rich accounts are often circumscribed or condensed, due to page or word restrictions in associated journals. As such, organizationally themed and rich accounts of historical events such as Sofsky's (1999) examination of the business-like concentration camps, which may be classified as a thick description (Rowlinson et al., 2013), tend to be confined to books.

We suggest that researchers should make use of the internet and data storage technology to employ the technique of data and source archiving. This technique refers to scholars storing and allowing others to access the electronic qualitative data that they have collected. These data could include research diaries, scans of archival documents, photographic and video materials or extracts from sources. Advocates of this approach such as the political scientists Colin Elman, Diana Kapiszewski, and Lorena Vinuela (2010) suggest that archiving qualitative data will promote secondary data analysis and allow scholars to engage in comparative historical research that previously had been prohibitively time consuming or costly. Sociologists such as Hammersley (1997) make similar claims, emphasizing that archived information could help to assess findings whilst also allowing social historians to conduct secondary analysis on archived data to facilitate comparative analysis.

Although there is little discussion of archiving within organization studies, Elman, Kapiszewski and Vinuela (2010) outline different qualitative data archival resources around 
the world. Many of these online resources offer support for researchers in terms of data deposit and reanalysis, such as The Qualitative Data Archival Resource Centre (QUALIDATA). Elman et al. (2010) note that QUALIDATA provides procedures for cataloguing, depositing and extracting data whilst also ensuring respondent confidentiality. As such, it seems reasonable to utilize new technology to collect and store such information to reduce the risk of personal data loss whilst also minimizing the transaction costs associated with data sharing (Elman et al., 2010). In these ways, archiving provides easier access to data, which, in turn, facilitates the comparison of contexts and a greater understanding of how an historian reached their contextualized conclusions.

\section{APPLYING THE PRINCIPLES AND TECHNIQUES}

As Lincoln and Guba (1985, p. 287) insisted, "In the final analysis, the study is for naught if its trustworthiness is questionable." Our use of trustworthy, which equates to open and transparent research, suggests the same. We contend that producing trustworthy accounts of the past opens up possibilities for discussion and engagement between organizational historians and organizational theorists.

As with any set of criteria or framework, there are boundary conditions or limits to the utility of our criteria of trustworthiness. Two of the most fundamental limits of the framework are the impossibility of acknowledging all methodological decisions and the diseconomies of using all the principles at once. In terms of the impossibility of acknowledging all methodological decisions, we do not suggest that all historians' decisions can be communicated to the reader or even completely captured by the researcher themselves. Our key ambition in this article is to highlight the inherent issues of interpretation that exist in historical narratives, where the role of the researcher cannot be ignored. As such, we offer a range of techniques that encourage greater transparency when developing historical 
interpretations thereby building more understanding between researcher and reader, opening up the possibility of dialogue with others. Reflecting the subjective nature of interpretation, we offer guidelines rather than methodological rules (Seale, 1999).

In terms of the diseconomies of using all the principles at once, we do not suggest that scholars should employ all of the proposed principles and associated techniques collectively in the researching or writing of their historical narratives. This may not be practical as, for example, the triangulation of methods or engagement with historians may not always be possible. Furthermore, strict adherence to a set of guidelines is likely to prevent scholarship rather than enhance it (Lustick, 1996). As such, these guidelines are not definitive or final but, instead, represent a contribution to an ongoing dialogue about how organizational scholars could conduct and communicate their historical research. A future step in developing such guidelines for narrative histories would be to consider how, when or why scholars should select a particular criterion at a particular time. As starting point, we suggest that scholars should consider each criterion and, where possible, attempt to employ a technique associated with each.

One significant implication of meeting the proposed criteria is that the detail and length of manuscripts may increase. Organizational historians may need to engage in much more depth with a larger number of historical materials and to do so explicitly. Although the advent on online publishing has lessened the potential impact of this problem, many journals and publishing groups continue to stipulate specific page or word limits. Such a restriction presents a potential tension between the tenets of trustworthiness and publication. It is important to reiterate that whilst we suggest that organizational historians engage with the historiography and explain their selection of sources, it is not encouraging them to repeat or re-write the content of all of these sources within their manuscripts. In many instances, organizational historians need only provide citations or explanatory footnotes so that readers 
and reviewers can investigate particular interpretations as necessary. Even when the criteria of trustworthiness call for the explanation of contentious or unique interpretations and the partial reproduction of substantiating sources, the suggestion is that these be located in an appendix or online archive.

We also believe that there is considerable potential to consider how the proffered criteria and principles may be valuable to narrative analysis and inquiry more broadly and not necessarily just for constructing historical narratives. The underlying premise of our notion of trustworthiness is to guide researchers in generating more transparent narratives that allow other scholars to build trust in them. Future scholarship could consider how this notion and our framework could be developed or employed to support narrative analysis performed in more contemporary settings.

Beyond the narrative approaches discussed here, there is an opportunity for management and organizational scholars to develop more formal guidance on how to apply other established research methodologies to engage with historical evidence. We have pointed out in this article that historical research raises a different set of challenges and opportunities when compared to contemporary field-based research. As such, we call for further methodological developments or refinements that can support historical organizational scholarship.

\section{CONCLUSION}

This article complements the emerging body of literature that provides guidance for organizational historians. In particular, we sought to support organizational historians in bringing their role in the construction of historical narratives to the fore and opening their research decisions up for discussion. We advanced the notion of trustworthiness as a framework to guide researchers in generating more transparent historical narratives, drawing 
on the underlying criteria of credibility, confirmability dependability and transferability (Lincoln and Guba, 1985). By translating each of these criterions into a series of principles and matching these with specific techniques that can be applied to historical research, we guide organizational scholars seeking to construct more transparent historical narratives. This guidance is valuable because historical narratives rely on interpretation, thus building insight into and understanding of these interpretations is essential if other organizational scholars are to engage with them.

The potential contribution of history to organizational theory is considerable. There is still a great opportunity for organizational scholars to engage with historical cases to elaborate, enrich and extend their theories. For example, we contend that the incorporation of trustworthy accounts of historical events would encourage greater sensitivity to historical context. As other social scientists have pointed out, such sensitivity could help to reveal the spatial and temporal bounds of a theory (Levy, 1997). Furthermore, historians' contextualized and rich interpretations provide an antidote to the stylized settings that underpin many theories (Clark and Rowlinson, 2004). There are also mutual benefits across disciplines, as theorists may help business historians to recognize commonalities or patterns in their historical accounts. We believe that greater transparency in historical narratives is likely to enhance their trustworthiness for theorists, providing an invitation to bring both the scholars and subjects of history and organizational theory closer together. 


\section{REFERENCES}

Alvesson, M. and K. Sköldberg (2009). Reflexive methodology: New vistas for qualitative research, Sage, London.

Arndt, M. and B. Bigelow (2005). 'Professionalizing and Masculinizing a Female Occupation: The Reconceptualization of Hospital Administration in the Early 1900s', Administrative Science Quarterly, 50, pp. 233-261.

Balogun, J. and G. Johnson (2004). 'Organizational Restructuring and Middle Manager Sensemaking', The Academy of Management Journal, 47, pp. 523-549.

Barrett, F. J. and S. Srivastval (1991). 'History as a Mode of Inquiry in Organizational Life: A Role for Human Cosmogony', Human Relations, 44, pp. 231-254.

Belk, R. W., J. F. Sherry, Jr. and M. Wallendorf (1988). 'A Naturalistic Inquiry into Buyer and Seller Behavior at a Swap Meet', Journal of Consumer Research, 14, pp. 449470.

Bennett, A. (2008). 'Process Tracing: A Bayesian Perspective'. In: J. M. Box-Steffensmeier, H. E. Brady and D. Collier (eds.), The Oxford handbook of political methodology. pp. 702-721. Oxford: OUP.

Boje, D. M. (1995). 'Stories of the Storytelling Organization: A Postmodern Analysis of Disney As "Tamara-Land”, Academy of Management Journal, 38, pp. 997-1035.

Bradshaw-Camball, P. and V. V. Murray (1991). 'Illusions and Other Games: A Trifocal View of Organizational Politics', Organization science, 2, pp. 379-398.

Bryant, J. M. (2000). 'On sources and narratives in historical social science: a realist critique of positivist and postmodernist epistemologies', The British Journal of Sociology, 51, pp. 489-523.

Bucheli, M. and R. D. Wadhwani (2014). Organizations in Time: History, Theory, Methods, OUP, Oxford.

Burrell, G. (1997). Pandemonium: Towards a retro-organization theory, Sage, London.

Bury, J. B. (1968). Selected essays, CUP, Cambridge.

Büthe, T. (2002). 'Taking Temporality Seriously: Modeling History and the Use of Narratives as Evidence', The American Political Science Review, 96, pp. 481-493.

Byman, D. and M. Waxman (2002). The dynamics of coercion: American foreign policy and the limits of military might, Cambridge University Press, Cambridge.

Carr, D. (1986). 'Narrative and the Real World: An Argument for Continuity', History and Theory, 25, pp. 117-131.

Carr, E. H. (1961). What is history?, Penguin Books, London.

Chandler, A. D. J. (1977). The visible hand: The managerial revolution in American business., Belknap/ Harvard University Press, Cambridge Mass.

Chia, R. (1996). Organizational analysis as deconstructive practice, Walter de Gruyter.

Clark, P. and M. Rowlinson (2004). 'The Treatment of History in Organisation Studies: Towards an 'Historic Turn'?', Business History, 46, pp. 331-352.

Collier, D. (2011). 'Understanding Process Tracing', PS: Political Science and Politics, 44, pp. 823-830.

Collingwood, R. G. (2005). The idea of history, Oxford University Press, Oxford.

Coraiola, D., W. M. Foster and R. Suddaby (2015). 'Varieties of History in Organization Studies'. In: P. G. McLaren, A. J. Mills and T. G. Weatherbee (eds.), The Routledge Companion to Management \& Organizational History. Routledge.

Corley, K. G. (2004). 'Defined by our strategy or our culture? Hierarchical differences in perceptions of organizational identity and change', Human Relations, 57, pp. 11451177.

Croce, B. (1921). History, its theory and practice (D. Ainslie, Trans.), Harcourt, New York. 
Czarniawska, B. (1997). A narrative approach to organization studies, Sage Publications.

Denzin, N. K. (1970). 'Triangulation: A case for methodological and combination evaluation: An introduction'. In: N. K. Denzin (ed.) Sociological methods: A sourcebook. pp. 471475. Chicago: Aldine.

Denzin, N. K. (1971). 'The Logic of Naturalistic Inquiry', Social Forces, 50, pp. 166-182.

Denzin, N. K. (1989). Interpretive interactionism, Sage, Newbury Park, CA.

Dray, W. H. (1971). 'On the Nature and Role of Narrative in Historiography', History and Theory, 10, pp. 153-171.

Eisenhardt, K. M. (1989). 'Building Theories from Case Study Research', The Academy of Management Review, 14, pp. 532-550.

Elman, C. (2004). 'Extending Offensive Realism: The Louisiana Purchase and America's Rise to Regional Hegemony', American Political Science Review, 98, pp. 563-576.

Elman, C. and M. F. Elman (1997). 'Diplomatic history and international relations theory: respecting difference and crossing boundaries', International Security, 22, pp. 5-21.

Elman, C., D. Kapiszewski and L. Vinuela (2010). 'Qualitative Data Archiving: Rewards and Challenges', PS: Political Science \& Politics, 43, pp. 23-27.

Elton, G. R. (2002). The practice of history, Blackwell, Oxford.

Fulmer, C. A. and M. J. Gelfand (2012). 'At What Level (and in Whom) We Trust', Journal of Management, 38, pp. 1167-1230.

Gabriel, Y. (2015). 'Reflexivity and beyond-a plea for imagination in qualitative research methodology', Qualitative Research in Organizations and Management: An International Journal, 10, pp. 332-336.

Garud, R., S. Jain and A. Kumaraswamy (2002). 'Institutional entrepreneurship in the sponsorship of common technological standards: The case of sun microsystems and java', Academy of Management Journal, 45, pp. 196-214.

George, A. L. (1997). 'Knowledge for Statecraft: The Challenge for Political Science and History', International Security, 22, pp. 44-52.

George, A. L. and A. Bennett (2005). Case studies and theory development in the social sciences, MIT Press, Cambridge, MA.

Gil, T. (2009). 'Leopold Ranke'. In: A. Tucker (ed.) A Companion to the Philosophy of History and Historiography. pp. 381-392. West Sussex: John Wiley \& Sons.

Gioia, D. A., K. N. Price, A. L. Hamilton and J. B. Thomas (2010). 'Forging an Identity: An Insider-outsider Study of Processes Involved in the Formation of Organizational Identity', Administrative Science Quarterly, 55, pp. 1-46.

Goldthorpe, J. H. (1991). 'The Uses of History in Sociology: Reflections on Some Recent Tendencies', The British Journal of Sociology, 42, pp. 211-230.

Greenwood, A. and A. Bernardi (2014). 'Understanding the rift, the (still) uneasy bedfellows of History and Organization Studies', Organization, 21, pp. 907-932.

Greenwood, R. and R. Suddaby (2006). 'Institutional Entrepreneurship In Mature Fields: The Big Five Accounting Firms', Academy of Management Journal, 49, pp. 27-48.

Griffin, L. J. (1992). 'Temporality, Events, and Explanation in Historical Sociology: An Introduction', Sociological Methods \& Research, 20, pp. 403-427.

Guba, E. G. (1981). 'ERIC/ECTJ Annual Review Paper: Criteria for Assessing the Trustworthiness of Naturalistic Inquiries', Educational Communication and Technology, 29, pp. 75-91.

Guba, E. G. and Y. S. Lincoln (1982). 'Epistemological and methodological bases of naturalistic inquiry', ECTJ, 30, pp. 233-252.

Guba, E. G. and Y. S. Lincoln (1994). 'Competing paradigms in qualitative research'. Handbook of qualitative research. pp. 163-194. Thousand Oaks: Sage. 
Halpern, E. S. (1983). 'Auditing Naturalistic Inquiries: The Development and Application of a Model'. Unpublished Doctoral Dissertation. Indiana University.

Hammersley, M. (1997). 'Qualitative Data Archiving: Some Reflections on its Prospects and Problems', Sociology, 31, pp. 131-142.

Hassard, J. (2012). 'Rethinking the Hawthorne Studies: The Western Electric research in its social, political and historical context', Human Relations, 65, pp. 1431-1461.

Hatch, M. J. (1996). 'The role of the researcher: An analysis of narrative position in organization theory', Journal of Management Inquiry, 5, pp. 359-374.

Haveman, H. A. (1993). 'Ghosts of Managers Past: Managerial Succession and Organizational Mortality', The Academy of Management Journal, 36, pp. 864-881.

Heidegger, M. (1996). Being and Time (J. Stambaugh, Trans.) SUNY Press, Albany.

Hempel, C. G. (1942). 'The Function of General Laws in History', Journal of Philosophy, 39, pp. $35-48$.

Hibbert, P., J. Sillince, T. Diefenbach and A. L. Cunliffe (2014). 'Relationally reflexive practice: a generative approach to theory development in qualitative research', Organizational Research Methods, 17, pp. 278-298.

Iggers, G. G. (1984). New directions in European historiography, Wesleyan University Press, New Hampshire.

Ingram, E. (1997). 'The wonderland of the political scientist', International Security, 22, pp. 53-63.

Jacques, R. S. (2006). 'History, historiography and organization studies: The challenge and the potential', Management \& Organizational History, 1, pp. 31-49.

Kieser, A. (1994). 'Why organization theory needs historical analyses - and how this should be performed', Organization science, 5, pp. 608-620.

Kipping, M., D. Wadhwani and M. Bucheli (2014). 'Analyzing and Interpreting Historical Sources : A Basic Methodology.'. In: M. Bucheli and D. Wadhwani (eds.), Organizations in Time: History, Theory, Methods. pp. 305-330. Oxford: Oxford University Press.

Larson, D. W. (2001). 'Sources and methods in Cold War history: The need for a new theorybased archival approach'. In: C. Elman and M. F. Elman (eds.), Bridges and Boundaries: Historians, Political Scientists, and the Study of International Relations. pp. 327-350. Cambridge: MIT Press.

Levy, J. S. (1997). 'Too Important to Leave to the Other: History and Political Science in the Study of International Relations', International Security, 22, pp. 22-33.

Lincoln, Y. S. (1995). 'Emerging Criteria for Quality in Qualitative and Interpretive Research', Qualitative Inquiry, 1, pp. 275-289.

Lincoln, Y. S. and E. G. Guba (1985). Naturalistic inquiry, Sage, Beverly Hills, CA.

Lincoln, Y. S. and E. G. Guba (2013). The constructivist credo, Left Coast Press, Walnut Creek, CA.

Lipartito, K. (2014). 'Historical Sources and Data'. In: M. Bucheli and D. Wadhwani (eds.), Organizations in Time: History, Theory, Methods. p. 284. Oxford: Oxford University Press.

Lustick, I. S. (1996). 'History, Historiography, and Political Science: Multiple Historical Records and the Problem of Selection Bias', The American Political Science Review, 90, pp. 605-618.

McKinlay, A. (2002). "Dead Selves': The Birth of the Modern Career', Organization, 9, pp. 595-614.

Megill, A. (1989). 'Recounting the Past: "Description," Explanation, and Narrative in Historiography', The American Historical Review, 94, pp. 627-653. 
Megill, A. (1991). 'Fragmentation and the Future of Historiography', The American Historical Review, 96, pp. 693-698.

Mink, L. O. (1970). 'History and Fiction as Modes of Comprehension', New Literary History, 1, pp. 541-558.

Mink, L. O. (2001). 'Narrative Form as a Cognitive Instrument'. In: G. Roberts (ed.) The history and narrative reader. pp. 211-220. London: Routledge.

Mishler, E. G. (1990). 'Validation in Inquiry-Guided Research: The Role of Exemplars in Narrative Studies', Harvard Educational Review, 60, pp. 415-443.

Moravcsik, A. (2010). 'Active Citation: A Precondition for Replicable Qualitative Research', PS: Political Science \& Politics, 43, pp. 29-35.

Munslow, A. (2006). Deconstructing history, Taylor \& Francis, Abingdon.

Novick, P. (1988). That Noble Dream: The 'Objectivity Question' and the American Historical Profession., Cambridge University Press, Cambridge.

O'Connor, E. (1999). 'The Politics of Management Thought: A Case Study of the Harvard Business School and the Human Relations School', The Academy of Management Review, 24, pp. 117-131.

O'Connor, E., M. J. Hatch, H. V. White and M. N. Zald (1995). 'Undisciplining Organizational Studies: A Conversation Across Domains, Methods, and Beliefs', Journal of Management Inquiry, 4, pp. 119-136.

Pettigrew, A. M. (2011). The Awakening Giant: Continuity and Change in Imperial Chemical Industries, Routledge, Abingdon.

Prasad, A. and P. Prasad (2002). 'The Coming of Age of Interpretive Organizational Research', Organizational Research Methods, 5, pp. 4-11.

Rhodes, C. (2001). Writing organization:(Re) presentation and control in narratives at work, John Benjamins Publishing.

Rhodes, C. and A. D. Brown (2005). 'Writing Responsibly: Narrative Fiction and Organization Studies', Organization, 12, pp. 467-491.

Ricoeur, P. (1965). History and truth, Northwestern University Press, Illinois.

Riessman, C. K. (1993). Narrative analysis, Sage.

Roberts, G. (2001). The history and narrative reader, Routledge, London.

Robinson, S. and R. Kerr (2015). 'Reflexive Conversations: Constructing Hermeneutic Designs for Qualitative Management Research', British Journal of Management, 26, pp. 777-790.

Roth, P. A. (1988). 'Narrative Explanations: The Case of History', History and Theory, 27, pp. 1-13.

Rowlinson, M. (2004). 'Historical analysis of company documents'. In: C. Cassell and G. Symon (eds.), Essential guide to qualitative methods in organizational research. pp. 301-311. London: Sage.

Rowlinson, M., J. Hassard and S. Decker (2013). 'Strategies for organizational history: A dialogue between historical theory and organization theory', Academy of Management Review.

Ruby, J. A. Y. (1980). 'Exposing yourself: Reflexivity, anthropology, and film', Semiotica, 30, pp. 153-179.

Rüsen, J. (1990). 'Rhetoric and Aesthetics of History: Leopold von Ranke', History and Theory, 29, pp. 190-204.

Schwandt, T. A. and E. S. Halpern (1988). Linking auditing and metaevaluation: enhancing quality in applied research, Sage, London.

Seale, C. (1999). 'Quality in Qualitative Research', Qualitative Inquiry, 5, pp. 465-478.

Shah, S. K. and K. G. Corley (2006). 'Building Better Theory by Bridging the QuantitativeQualitative Divide', Journal of Management Studies, 43, pp. 1821-1835. 
Skocpol, T. (1984). Vision and method in historical sociology, CUP, Cambridge.

Smoke, R. (1977). War: Controlling Escalation, Harvard University Press, Cambridge, Mass.

Sofsky, W. (1999). The order of terror: The concentration camp (W. Templar, Trans.), Princeton University Press, Princeton, N.J.

Stone, L. (1979). 'The Revival of Narrative: Reflections on a New Old History', Past \& Present, pp. 3-24.

Strauss, A. and J. Corbin (1990). Basics of Qualitative Research: Grounded Theory, Procedures and Techniques, Sage, Newbury Park, California.

Suddaby, R., W. Foster and A. J. Mills (2014). 'Historical Institutionalism'. In: M. Bucheli and D. Wadhwani (eds.), Organizations in Time: History, Theory, Methods. pp. 100123. Oxford: Oxford University Press.

Sydow, J., G. Schreyögg and J. Koch (2009). 'Organizational Path Dependence: Opening the Black Box', Academy of Management Review, 34, pp. 689-709.

Thies, C. G. (2002). 'A Pragmatic Guide to Qualitative Historical Analysis in the Study of International Relations', International Studies Perspectives, 3, pp. 351-372.

Tilly, C. (1999). 'Historical sociology'. In: N. J. Smelser and P. B. Baltes (eds.), International Encyclopedia of the Social and Behavioral Sciences. Amsterdam: Elsevier.

Tippmann, E., V. Mangematin and P. S. Scott (2013). 'The Two Faces of Knowledge Search: New Solutions and Capability Development', Organization studies, 34, pp. 18691901.

Tønnesson, S. (2012). 'Active citation through hyperlinks: The retarded replication revolution', International Area Studies Review, 15, pp. 83-90.

Trachtenberg, M. (2009). The craft of international history: A guide to method, Princeton University Press, New Jersey.

Trethewey, A. (1999). 'Disciplined Bodies: Women's Embodied Identities at Work', Organization studies, 20, pp. 423-450.

Üsdiken, B. and A. Kieser (2004). 'Introduction: History in Organisation Studies', Business History, 46, pp. 321-330.

Von Ranke, L. (2010). The Theory and Practice of History. Edited with an introduction by Georg G. Iggers, Taylor \& Francis, Abingdon.

Warren, R. and G. Tweedale (2002). 'Business Ethics and Business History: Neglected Dimensions in Management Education', British Journal of Management, 13, pp. 209219.

White, H. V. (1973). 'Interpretation in History', New Literary History, 4, pp. 281-314.

White, H. V. (1975). Metahistory: The historical imagination in nineteenth-century Europe, JHU Press, Maryland.

White, H. V. (1984). 'The Question of Narrative in Contemporary Historical Theory', History and Theory, 23, pp. 1-33.

Yates, J. (2014a). 'Understanding Historical Methods in Organization Studies'. In: M. Bucheli and D. Wadhwani (eds.), Organizations in Time: History, Theory, Methods. p. 265. Oxford: Oxford University Press.

Yates, J. (2014b). 'Understanding historical methods in organization studies'. In: M. Bucheli and R. D. Wadhwani (eds.), Organizations in Time: History, Theory, Methods. Oxford: OUP.

Zald, M. N. (1993). 'Organization Studies As a Scientific and Humanistic Enterprise: Toward a Reconceptualization of the Foundations of the Field', Organization science, 4, pp. 513-528.

Zald, M. N. (1996). 'More Fragmentation? Unfinished Business in Linking the Social Sciences and the Humanities', Administrative Science Quarterly, 41, pp. 251-261. 
TABLE 1

Guiding Criteria, Principles and Techniques for Enhancing the Trustworthiness of Historical Narratives

\begin{tabular}{|c|c|c|c|}
\hline CRITERIA & UNDERLYING PRINCIPLES & PROPOSED TECHNIQUES & EXAMPLES \\
\hline \multirow[t]{2}{*}{ 1. Credibility } & $\begin{array}{l}\text { Engage with the content and context of } \\
\text { sources }\end{array}$ & Source criticism & $\begin{array}{l}\text { Arndt and Bigelow } \\
(2005)\end{array}$ \\
\hline & Discuss interpretations & Expert (historian) checks & Smoke (1977) \\
\hline \multirow[t]{2}{*}{ 2. Confirmability } & Reveal underlying assumptions & $\begin{array}{l}\text { Identification of the school or strategy of } \\
\text { historiography }\end{array}$ & McKinlay (2002) \\
\hline & $\begin{array}{l}\text { Ensure interpretations are grounded in } \\
\text { evidence }\end{array}$ & Active citation and footnoting & Hassard (2012) \\
\hline \multirow[t]{2}{*}{ 3. Dependability } & Adopt different approaches to research & Triangulation of sources, methods and inquirers & Pettigrew (2011) \\
\hline & $\begin{array}{l}\text { Allow others to comment on the process of } \\
\text { research }\end{array}$ & $\begin{array}{l}\text { Reflexive accounts of qualitative judgments, } \\
\text { through process tracing }\end{array}$ & Rowlinson (2004) \\
\hline \multirow[t]{2}{*}{ 4. Transferability } & $\begin{array}{l}\text { Build a richly contextualized account of the } \\
\text { case(s) under study }\end{array}$ & Purposive and theoretical sampling & Chandler (1977) \\
\hline & $\begin{array}{l}\text { Permit comparison of context under study to } \\
\text { other contexts }\end{array}$ & Data and source archiving & $\mathrm{N} / \mathrm{A}$ \\
\hline
\end{tabular}

